\title{
REMOVAL OF AMMONIA BY CLINOPTILOLITE
}

\author{
M. ZABOCHNICKA-ŚWIĄTEK* \\ K. MALIŃSKA
}

Częstochowa University of Technology Institute of Environmental Engineering

Brzeźnicka 60a, 42-200 Częstochowa, Poland
Received: 31/05/10

Accepted: 08/09/10 *to whom all correspondence should be addressed: e-mail: mzabochnicka@is.pcz.czest.pl

\section{ABSTRACT}

The important advantage of zeolite applied to water treatment is its high porosity when comparing to other minerals. The porosity results in good hydrodynamic properties (the increase in the pressure loss on the zeolite filters is 1.5-2.0 times smaller than in the case of sand filters) and adsorption roperties, and in turn high capacity which allows for adsorption of contaminants (a clinoptilolite filter allows for removal of phytoplankton and bacteria).

The increase in the application of artificial fertilizers and gradual contamination of water resulted from discharging industrial wastewater into the environment led to the contamination of the environment by nitric compounds. Wastewater contains about $15-50 \mathrm{mg} \mathrm{dm}^{-3}$ of nitric compounds (based on nitrogen) - ammonia salts constitute about $55-60 \%$ whereas organic forms of proteins, pesticides and aminoacids about $40-50 \%$.

Natural clinoptilolite could be applied to remove ammonium ions from water and wastewater. The ammonium ion uptake behaviour of clinoptilolite is connected to the processes of ion exchange. The main aim of this investigation is to evaluate the adsorption capacity of clinoptilolite towards ammonium ions. According to the obtained results the adsorption capacity of clinoptilolite for the removal of ammonium ions demonstrates its potential application in the treatment of water, wastewater and sanitary landfill leachate contaminated with ammonia. The highest adsorption capacity of clinoptilolite towards ammonium ions of $3.79 \mathrm{mg} \mathrm{g}^{-1}$ was found for the initial concentration of $300 \mathrm{mg} \mathrm{L}^{-1}$. The highest removal level reached by clinoptilolite for ammonium was of $99.74 \%$ for the initial concentration of ammonia of $50 \mathrm{mg} \mathrm{L}^{-1}$. The effect of exposure time on maximum uptake of ammonia was found to be insignificant.

KEYWORDS: clinoptilolite; ammonium ion removal; ion exchange.

\section{INTRODUCTION}

Zeolites possess a net negative structural charge resulting from isomorphic substitution of cations in the crystal lattice (Faghihian and Bowman, 2005). Minerals from the zeolite group differ from one another in the content of $\mathrm{Si}$ and Al. Clinoptilolite is the most common and abundant high-siliceous zeolite. The ratio of Si/Al in clinoptilolite is 5.7. Clinoptilolite belongs to the heulandite group. It has a two-dimensional channel system that allows the mineral to act as a molecular sieve (Bowman, 2003; Sullivan et al., 1998). Moreover, this zeolite shows high sorption and ion-exchange capacity, ionexchange selectivity, catalytic activity and structural temperature stability up to $700-750^{\circ} \mathrm{C}$ (Zabochnicka-Swiatek and Stepniak 2008).

The increase in the concentration of nitric compounds in aquifers results from the application of artificial fertilizers, and also is caused by discharging contaminated water from various industrial processes. Clinoptilolite shows highly selective capacity of adsorption towards $\mathrm{N}-\mathrm{NH} 4+$, and thus can be applied to remove ammonia from wastewater (Sprynskyy, 2005). The mechanism of ammonia nitrogen removal by means of clinoptilolite is based on the ion-exchange with the cations of an ion-exchanger. Ammonia nitrogen can be also removed through adsorption in the skeletal pores of the zeolite. The extraction degree increases inversely proportional to the reduction of the 
mineral fraction. The efficiency of ammonia removal is strongly affected by temperature. The higher the temperature, the higher the removal degree is achieved. The adsorbents can be easily regenerated and reused. Clinoptilolite easily adsorb the ions of potassium, ammonia, calcium, sodium and magnesium and many other (Sprynskyy, 2005; Zabochnicka-Świątek, 2007).

The important advantage of zeolite applied to water treatment is its high porosity when compared to other minerals. The porosity results in good hydrodynamic properties (the increase in the pressure loss on the zeolite filters is 1.5-2.0 times smaller than in the case of sand filters) and adsorption properties; its high capacity allows for adsorption of contaminants (a clinoptilolite filter allows for removal of phytoplankton and bacteria) (Kowal and Świderska-Bróż, 2000)

The increase in the application of artificial fertilizers and gradual contamination of water resulted from discharging industrial wastewater into the environment led to the increase in the concentration of nitric compounds in aquifers. Wastewater contains about $15-50 \mathrm{mg} \mathrm{dm}^{-3}$ of nitric compounds (based on nitrogen) - ammonia salts constitute about $55-60 \%$ whereas organic forms of proteins, pesticides, and aminoacids about $40-50 \%$. These compounds, particularly pesticides are harmful and significantly decrease the quality of water. High concentrations of these compounds can result in poisoning the aquifer fauna, and also can stimulate its autoeutrophication (Rüffer and Rosenwinkel, 1998). Molecular sieves obtained from sedimentary forms of natural clinoptilolite are applied to remove ammonium ions from water (Sprynskyy, 2005).

According to the conducted research the natural zeolites have sedimentary origin, particularly tuff containing clinoptilolite and modernite can be successfully applied as substitutes of zeolites synthetized on the adsorbents used for enriching air with oxygen.

According to Gomółka and Szaynok (1997), ammoniacal nitrogen is present in two forms when in water: ammonia $\left(\mathrm{NH}_{3}\right)$ or ammonium $\left(\mathrm{NH}_{4}{ }^{+}\right)$:

$\mathrm{NH}_{4}^{+}+\mathrm{OH}^{-} \Leftrightarrow \mathrm{NH}_{3}+\mathrm{H}_{2} \mathrm{O}$
$\mathrm{NH}_{3}+\mathrm{H}_{3} \mathrm{O}^{+} \Leftrightarrow \mathrm{NH}_{4}^{+}+\mathrm{H}_{2} \mathrm{O}$

The ammonium ion uptake behavior of clinoptilolite is connected to the processes of ion exchange (Weatherley and Miladinovic, 2004). The main aim of this investigation is to evaluate the adsorption capacity of clinoptilolite for ammonium ions.

\section{MATERIALS AND METHODS}

The Hungrian clinoptilolite was used in the investigations. The grain size of clinoptilolite was in the range of $0.0-0.125 \mathrm{~mm}$ and the mineralogical composition was $55 \%$ of clinoptilolite, $6 \%$ of quartz, $13 \%$ of montmorillonite, $26 \%$ of volcanic ash. It has a surface area up to $1500 \mathrm{~m}^{2} \mathrm{~g}^{-1}$.

The investigations on the adsorption capacity of clinoptilolite for ammonium ions were conducted in two phases: (1) the preliminary investigations and (2) the main investigations. The preliminary investigations aimed at the evaluation of the impact of selected amounts of clinoptilolite on the removal degree of $\mathrm{N}_{-} \mathrm{NH}_{4}{ }^{+}$in the following concentrations $50,100,300$, and $500 \mathrm{mg} \mathrm{L}^{-1} \mathrm{~N}-\mathrm{NH}_{4}{ }^{+}$. The samples with the addition of $1 \mathrm{~g}$ of clinoptilolite were shaken for 30 minutes. The removal degree of ammonium ions was evaluated. With the reference to the obtained results from the preliminary investigations further experiments were conducted with $2 \mathrm{~g}$ of clinoptilolite in order to achieve higher degree of ammonium ions removal. Also, the exposure time of the mineral and the solution was extended to determine the effect of time exposure on the amount of removed $\mathrm{N}^{-\mathrm{NH}_{4}}{ }^{+}$ions.

Four solutions with the following concentrations: 50,100,300, and $500 \mathrm{mg} \mathrm{L}^{-1} \mathrm{~N}_{-} \mathrm{NH}_{4}{ }^{+}$were prepared from the standard solution of ammonium chloride at concentration of $1 \mathrm{~g} \mathrm{~L}^{-1}$ These solutions were subjected to the $\mathrm{pH}$ analysis performed with the potentiometric method. Samples of 1 and $2 \mathrm{~g}$ of clinoptilolite were weighed and $100 \mathrm{ml}$ of N-NH${ }_{4}{ }^{+}$solutions were added. The prepared samples were shaken for 30,60 and 180 minutes and after that the $\mathrm{pH}$ was measured. Next, the samples were filtered in order to determine the concentration of ammoniacal nitrogen. Each solution was prepared in triplicates.

The ammonium concentration of the aqueous phase was determined by the standard distillation method. Prior to the determination of ammoniacal nitrogen the filtered samples were subjected to distillation $(\mathrm{BÜCHI} 323)$ and the concentration of $\mathrm{N}^{-} \mathrm{NH}_{4}^{+}$was determined using spectrophotometer (Hach). 


\section{DATA ANALYSIS}

The degree of ammonia removal (\%) from the investigated solutions was calculated from the following formula:

Uptake $(\%)=\frac{\mathrm{C}_{0}-\mathrm{C}_{\mathrm{k}}}{\mathrm{C}_{0}} 100$

Where: $\mathrm{C}_{0}$ and $\mathrm{C}_{\mathrm{k}}$ : the initial and final concentration $\left(\mathrm{mg} \mathrm{L}^{-1}\right)$.

The sorption capacity was calculated from the following equation:

$A=\frac{\left(C_{0}-C_{k}\right)}{m} V$

where: $A$ : the adsorption capacity $\left(\mathrm{mg} \mathrm{g}^{-1}\right) ; C_{0}$ and $C_{k}$ : the initial and final concentration $\left(\mathrm{mg} \mathrm{L}^{-1}\right)$;

$\mathrm{V}$ : the sample volume (L); $\mathrm{m}$ : the clinoptilolite weight $(\mathrm{g})$.

\section{RESULTS}

The initial and final $\mathrm{pH}$ values, removal degree and adsorption capacity of tested samples for 1 and $2 \mathrm{~g}$ of clinoptilolite for exposure time of $30 \mathrm{~min}$. are presented in Table 1.

Table 1. The initial and final $\mathrm{pH}$ values, removal degree and adsorption capacity

\begin{tabular}{lcccc}
\hline $\begin{array}{l}\mathrm{C}_{0} \\
\left(\mathrm{mg} \mathrm{L}^{-1} \mathrm{~N}_{-\mathrm{NH}_{4}}{ }^{+}\right)\end{array}$ & Initial pH & Final $\mathrm{pH}$ & $\begin{array}{c}\text { Uptake } \\
(\%)\end{array}$ & $\begin{array}{c}\mathrm{A} \\
\left(\mathrm{mg} \mathrm{g}^{-1}\right)\end{array}$ \\
\hline $1 \mathrm{~g}$ of clinoptilolite & & & & \\
\hline 50 & 6.11 & 6.53 & 81.90 & 1.02 \\
\hline 100 & 6.25 & 6.40 & 60.80 & 1.52 \\
\hline 300 & 6.23 & 6.47 & 35.13 & 2.64 \\
\hline 500 & 6.17 & 6.41 & 25.57 & 3.20 \\
\hline $2 \mathrm{~g}$ of clinoptilolite & & & & \\
\hline 50 & 6.15 & 6.65 & 84.88 & 1.06 \\
\hline 100 & 6.34 & 6.78 & 79.97 & 2.00 \\
\hline 300 & 6.53 & 6.79 & 49.60 & 3.72 \\
\hline 500 & 6.41 & 6.95 & 28.88 & 3.61 \\
\hline
\end{tabular}

A slight increase in $\mathrm{pH}$ values was observed. The initial $\mathrm{pH}$ values were within the range of 6.11 to 6.53 and the final $\mathrm{pH}$ values were within the range of 6.41 to 6.95 . The higher $\mathrm{pH}$ values were observed for the samples with addition of $2 \mathrm{~g}$ of clinoptilolite.

The removal degree $>60 \%$ for initial concentration of 50 and $100 \mathrm{~N}-\mathrm{NH}_{4}{ }^{+}$for 30 min was observed, while uptake of $<50 \%$ for initial concentration of 300 and $500 \mathrm{~N}-\mathrm{NH}_{4}{ }^{+}$was found. According to the data presented in Table 1 the adsorption capacity of clinoptilolite was in the range of $1.02-3.20$ for $1 \mathrm{~g}$ of clinoptilolite and slightly higher adsorption capacity of 1.06-3.61 for $2 \mathrm{~g}$ of clinoptilolite was found.

The adsorption capacity of clinoptilolite for the removal of ammonium ion demonstrates its potential application in the treatment of solution contaminated with ammonia at different levels of concentration.

In order to reach the higher uptake of $\mathrm{N}^{-N_{4}}{ }_{4}^{+}$the higher amounts of clinoptilolite $(2 \mathrm{~g})$ and the longer time of contact were investigated.

The initial and final $\mathrm{pH}$ values of tested samples for $2 \mathrm{~g}$ of clinoptilolite and for time exposure of 60 and 180 min are presented in Table 2. The obtained results indicate that $\mathrm{pH}$ values are important parameters for ammonia removal.

In Figure 1 the uptake (\%) of ammonia for $2 \mathrm{~g}$ of clinoptilolite and for exposure time of 60 and 180 min is presented. 
Table 2. The initial and final $\mathrm{pH}$ values for 60 and $180 \mathrm{~min}$.

\begin{tabular}{lcc}
\hline $\begin{array}{l}\mathrm{C}_{0} \\
{\left[\mathrm{mg} \mathrm{L}^{-1} \mathrm{~N}^{-\mathrm{NH}_{4}}{ }^{+}\right]}\end{array}$ & Initial pH & Final pH \\
\hline Exposure time $-60 \mathrm{~min}$ & & \\
\hline 50 & 6.09 & 6.76 \\
\hline 100 & 6.24 & 6.69 \\
\hline 300 & 6.57 & 6.71 \\
\hline 500 & 6.43 & 6.93 \\
\hline Exposure time - 180 min & & \\
\hline 50 & 6.09 & 6.64 \\
\hline 100 & 6.24 & 6.52 \\
\hline 300 & 6.57 & 6.91 \\
\hline 500 & 6.43 & 6.96 \\
\hline
\end{tabular}

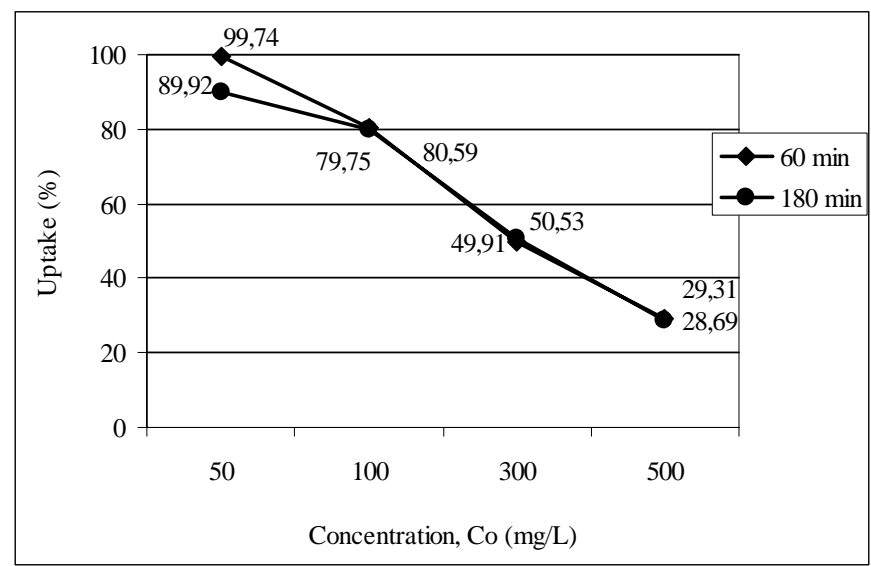

Figure 1. Percentage removal of ammonia by clinoptilolite for exposure time of 60 and $180 \mathrm{~min}$

Based on the conducted investigations ammonia is adsorbed with higher efficiency from the solutions at low concentrations.

The highest removal level of ammonia reached by clinoptilolite was in the range of $89.92-99.74 \%$ after 60 and $180 \mathrm{~min}$ of time exposure at the lowest ammonia concentration of $50 \mathrm{mg} \mathrm{L}^{-1}$. The lowest uptake of ammonia in the range of $28.69-29.31 \%$ was found at the highest ammonia concentration of $500 \mathrm{mg} \mathrm{L}^{-1}$. At initial concentration of 100,300 , and $500 \mathrm{mg} \mathrm{L}^{-1}$ the uptake was almost at the same level and the exposure time did not influence the process of ammonia removal from solution.

The Langmuir isotherm of ammonium removal by $2 \mathrm{~g}$ of clinoptilolite for exposure time of 60 and 180 min. is presented in Figure 2.

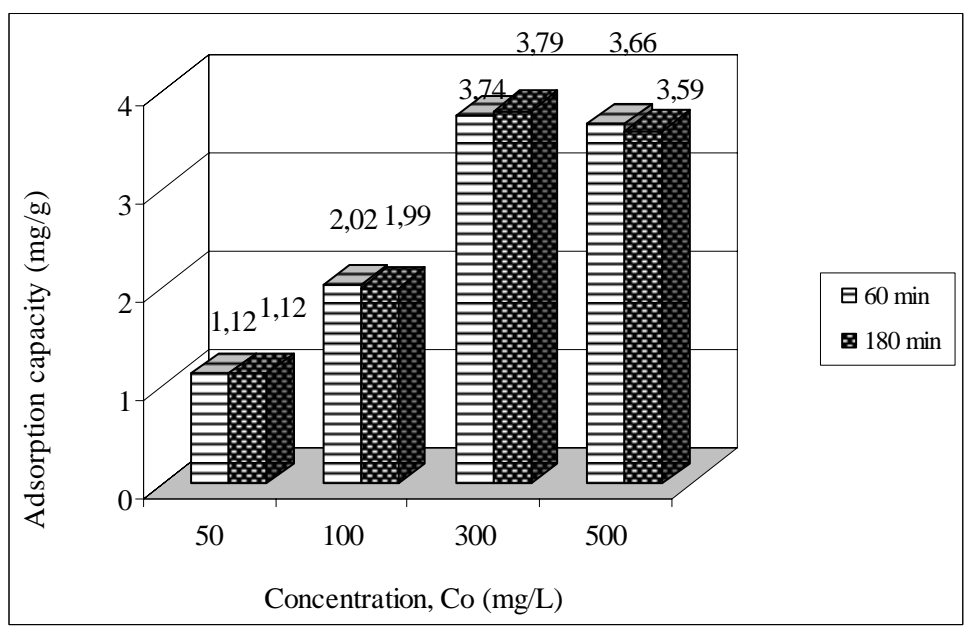

Figure 2. The Langmuir isotherm of ammonium removal for exposure time of 60 and $180 \mathrm{~min}$. 
The adsorption capacity of clinoptilolite was influenced by the concentration of ammonia. According to the data presented in figure 1 the highest adsorption capacity of clinoptilolite for initial concentration of $300 \mathrm{mg} \mathrm{L}^{-1}$ towards ammonia of $3.74 \mathrm{mg} \mathrm{g}^{-1}$ and $3.79 \mathrm{mg} \mathrm{g}^{-1}$ was found for time exposure of 60 and 180, respectively. The lowest adsorption capacity of clinoptilolite of $1.12 \mathrm{mg} / \mathrm{g}$ was found for the initial concentration of ammonia of $50 \mathrm{mg} \mathrm{L}^{-1}$.

Farkas et al., (2005) found that the exchange of ammonium ions amounted to $4.2 \mathrm{mg} \mathrm{g}^{-1}$ zeolite. Addition of activated carbon, regardless of its mass, increased the exchange of ammonium ions to only $5.7 \mathrm{mg} \mathrm{g}^{-1}$ zeolite.

Sprynskyy et al. (2005) investigated ammonium sorption from aqueous solutions by the natural zeolite Transcarpathian clinoptilolite. The researchers found that ammonium uptake onto the zeolite occurs by exchange with $\mathrm{Na}^{+}, \mathrm{Ca}^{2+}$, and $\mathrm{K}^{+}$ions. Although $\mathrm{Na}^{+}$ions were observed to be more easily exchanged for both hydrogen and ammonium ions, the role of $\mathrm{Ca}^{2+}$ ions increased with zeolite saturation by $\mathrm{NH}_{4}{ }^{+}$ions. The maximum sorption capacity of the Transcarpathian clinoptilolite toward ammonium evaluated under dynamic conditions varies in the interval $13.56-21.52 \mathrm{mg} \mathrm{g}^{-1}$, being significantly higher than determined under static conditions. This was conditioned by higher concentration gradients, by constant removal of exchange products under dynamic conditions and by flow rate value.

The exchange process is influenced by the presence of other ions in solution (Zabochnicka-Swiatek 2007; Inglezakis et al., 2005). The presence of competitive ions in solution could lead to pore clogging. Kaleta et al. (2007) investigated the application of clinoptilolite in water and wastewater treatment. The researchers found that the uptake of ammonia was lowered up to $80 \%$ in the presence of high concentration of calcium. Jorgensen and Weatherley (2003) investigated ammonia removal from wastewater by clinoptilolite in the presence of organic contaminants. The researchers indicated that the presence of organic compounds enhances the uptake of ammonium ion onto the ion exchangers.

Baykal and Guven (1997) found that clinoptilolite could be used for the removal of ammonia peaks from domestic wastewater. They also found that the loss of capacity of clinoptilolite after 10 regenerations in the sand filter with clinoptilolite where biological activity was enhanced was observed to be $10 \%$.

Karadag et al. (2008) indicated that clinoptilolite could be used for ammonium removal from sanitary landfill leachate. The researchers also found that equilibrium was reached at $3 \mathrm{~h}$ and highest value of ammonium exchanged was $20.37 \mathrm{mg} \mathrm{g}^{-1}$ for the concentration of $3750 \mathrm{mg} \mathrm{L}^{-1}$. The highest value of ammonium removal was obtained at $\mathrm{pH} 7$ as $57.8 \%$. For the concentration of $402 \mathrm{mg} \mathrm{L}^{-1}$ and 200 $\mathrm{mg} \mathrm{L}^{-1}$ the ammonium removal of $5 \mathrm{mg} \mathrm{g}^{-1}$ and $3 \mathrm{mg} \mathrm{g}^{-1}$ was observed, respectively. They observed that stirring time and concentration has an important role on the ammonium removal capacity of clinoptilolite. Increasing of both stirring time and ammonium concentration promoted amount of ammonium uptake.

\section{CONCLUSIONS}

In the present study, the sorption capacity of natural zeolite clinoptilolite to remove ammonium ions from water solutions has been investigated. According to the obtained results the following conclusions can be drawn:

- The adsorption capacity of clinoptilolite for the removal of ammonium ions demonstrates its potential application in the treatment of water, wastewater and sanitary landfill leachate contaminated with ammonia.

- The highest adsorption capacity of clinoptilolite towards ammonium ions of $3.79 \mathrm{mg} \mathrm{g}^{-1}$ was found for the initial concentration of $300 \mathrm{mg} \mathrm{L}^{-1}$.

- The highest removal level reached by clinoptilolite for ammonium was of $99.74 \%$ for the initial concentration of ammonia of $50 \mathrm{mg} \mathrm{L}^{-1}$.

- The effect of exposure time on maximum uptake of ammonia was found to be insignificant.

\section{ACKNOWLWDGEMENTS}

This study was carried out within the frame of the BW 401/206/08 State Committee for Scientific Research (KBN) in Poland. 


\section{REFERENCES}

Baykal B.B. and Guven D.A. (1997) Performance of clinoptilolite alone and in combination with sand filters for the removal of ammonia peaks from domestic wastewater, Wat. Sci. Tech., 35(7), 47-54.

Bowman R.S. (2003) Applications of surfactant-modified zeolites to environmental remediation, Micrioporous and Mesoporous Materials, 61, 43-56.

Faghihian H. and Bowman R.S. (2005) Adsorption of chromate by clinoptilolite exchanged with various metal cations, Water Research, 39, 1099-1104.

Farkaš A., Rožic M. and Barbaric-Mikocevic Z. (2005) Ammonium exchange in leakage waters of waste dumps using natural zeolite from the Krapina region, Croatia, Journal of Hazardous Materials, B117, 25-33.

Gomółka E. and Szaynok A. (1997) Water and air chemistry - (Chemia wody i powietrza), Oficyna Wydawnicza Politechnik Wrocławskiej (in Polish).

Inglezakis V.J., Zorpas A.A., Loizidou M.D. and Grigoropoulou H.P. (2005) The effect of competitive cations and anions on ion exchange of heavy metals, Separation and Purification Technology, 46, 202-207.

Jorgensen T.C. and Weatherley L.R. (2003) Ammonia removal from wastewater by ion exchange in the presence of organic contaminants, Water Research, 37, 1723-1728.

Kaleta J., Papciak D. and Puszkarewicz A. (2007) Clinoptilolites and diatomaceous earth in water and wastewater treatment - (Klinoptylolity i diatomity w aspekcie przydatności w uzdatnianiu wody $\mathrm{i}$ oczyszczaniu ścieków), Gospodarka surowcami mineralnymi, t.23, zeszyt 3, 21- 34 (in Polish).

Karadag D., Tok S., Akgul E., Turan M., Ozturk M. and Demir A. (2008) Ammonium removal from sanitary landfill leachate using natural Gordes clinoptilolite, Journal of Hazardous Materials, 153, 60-66.

Kowal A.L. and Świderska-Bróż M. (2000) Water treatment - (Oczyszczanie wody), Wydawnictwo Naukowe PWN, Warszawa-Wrocław (in Polish).

Rüffer H, Rosenwinkel K.H. (1998) Industrial wastewater treatment - (Oczyszczanie ścieków przemysłowych), Projprzem-EKO (in Polish)

Sprynskyy M., Lebedynets M., Terzyk A.P., Kowalczyk P., Namieśnik J. and Buszewski B. (2005) Ammonium sorption from aqueous solutions by the natural zeolite Transcarpathian clinoptilolite studied under dynamic conditions, Journal of Colloid and Interface Science, 284, 408-415.

Sullivan E.J., Carey J.W. and Bowman R.S. (1998) Thermodynamics of cationic surfactant sorption onto natural clinoptilolite, Journal of Colloid and Interface Science, 206, 369-380.

Weatherley L.R. and Miladinovic N.D. (2004) Comparison of the ion exchange uptake of ammonium ion onto New Zeland clinoptilolite and mordenite, Water Research, 38, 4305-4312.

Zabochnicka-Świątek M. and Stępniak L. (2008) The potential applications of aluminosilicates for metals removal from water, Proceedings from $2^{\text {nd }}$ International Conference Metals and related substances in drinking water, Cost Action 637, 29-31 October 2008, Lisbon, Portugal, 168-179.

Zabochnicka-Świątek M. (2007) Factors affecting adsorption capacity and ion selectivity of clinoptilolite towards heavy metal cations (Czynniki wpływajacce na pojemność adsorpcyjna i selektywność jonowymienną klinoptylolitu wobec kationów metali ciężkich), Inżynieria i Ochrona Środowiska, Częstochowa 2007, tom 10, nr 1, 27-43 (in Polish). 